\title{
Modalidades de tradução, prosódia semântica e tradução jornalística: Um estudo de caso baseado na tradução de um artigo do jornal The New York Times por dois veículos brasileiros ${ }^{1}$
}

Vanessa Domingues Prata*

\section{Introdução}

Uma questão bastante discutida em Jornalismo diz respeito à busca pela objetividade e pela neutralidade ao apurarmos e escrevermos as matérias, embora tais conceitos sejam difíceis de definir. Afinal, o que é ser objetivo? O que é ser neutro? A neutralidade e a objetividade são, de fato, princípios possíveis de serem atingidos não só em textos jornalísticos, mas em qualquer outro? Ao selecionarmos os fatos e darmos prioridade a alguns em detrimento de outros, a noção de objetividade e neutralidade já costuma se perder. Os mesmos conceitos, além das noções de equivalência, de Nida (1964), podem ser debatidos ao tratarmos de Tradução Jornalística, uma vez que, muitas vezes, o texto de chegada é um novo texto e não apenas a tradução literal do texto-fonte, se considerarmos tradução literal como palavra por palavra, conforme Vinay e Darbelnet ([1958] 1995).

Critérios jornalísticos, como o espaço na página do jornal ou revista para o texto traduzido, o público-alvo, a relevância do assunto e o próprio conhecimento dos leitores sobre o tema, podem interferir nas decisões do tradutor (ou do editor, mais frequentemente). A objetividade e a neutrali-

\footnotetext{
${ }^{1} \mathrm{O}$ presente artigo foi adaptado do trabalho de conclusão da pós-graduação latu sensu em Tradução pelo Centro Universitário Anhanguera (ex-Unibero), permanecendo inédito até o momento.

* Mestranda em Estudos da Tradução pela Universidade de São Paulo.
} 
dade em tradução jornalística passam a ter como alvo o fato gerador da notícia e não o texto-fonte em si. Como citado por Zipser e Polchlopek (2007, p. 9):

\begin{abstract}
Partimos não necessariamente de um TF (texto-fonte), mas de um FF (fatofonte) ou fato-gerador que se constitui no próprio evento noticioso. [...] a "transcodificação isenta" é para a tradução o que a "neutralidade" representa para o jornalismo. Entretanto, considerar a possibilidade de que existam textos neutros e imparciais significa desconsiderar a linguagem como manifestação cultural, resultando na sua desvinculação como produto de um meio social e como processo formador de sentido.
\end{abstract}

Assim, partindo do pressuposto de que qualquer tradução jornalística terá características próprias, como o foco no público-alvo, o fato de estar subordinada às questões editoriais do veículo em que será publicada e possíveis restrições de espaço, no caso de publicações impressas, analisaremos duas traduções da matéria “Brazilian leader's tippling becomes national concern", do jornalista americano Larry Rohter, publicado no jornal The New York Times em 9 de maio de 2004. Uma das traduções recebeu o título em português de "Hábitos etílicos de Lula se tornam preocupação nacional", traduzido por George El Khouri Andolfato e publicado no portal UOL também em 9 de maio de 2004, e a outra tradução foi intitulada "Hábito de bebericar do presidente vira preocupação nacional", sem indicação do tradutor, publicado no jornal Folha de S. Paulo na mesma data.

\title{
Objetivos
}

Este trabalho visa a analisar as traduções de um mesmo artigo do jornal The New York Times feitas pelo jornal brasileiro Folha de S. Paulo e pelo portal brasileiro de internet Universo On-Line (UOL). Com isso, pretendemos identificar as principais características dessas traduções, a partir das modalidades propostas por Aubert (1998, p. 1-25), e o impacto que as escolhas lexicais pode causar nos leitores brasileiros, baseando-nos no conceito de prosódia semântica da Linguística de Corpus, descrito por Berber Sardinha (2004, p. 235-250). 
Pretendemos ainda avaliar se as traduções brasileiras mantiveram-se "fiéis" ao texto original, segundo o conceito de equivalência formal (Nida, 1964), ou se foram adaptadas ao público-alvo (equivalência dinâmica, segundo Nida), além de ressaltar aos leitores que ler uma tradução de um artigo jornalístico do New York Times ou de qualquer outro periódico internacional não é o mesmo que ler o texto original desse veículo, mas, sim, um outro texto com todas as adaptações, cortes e escolhas que possam ter ocorrido durante o processo de tradução.

\section{Justificativa}

Embora a tradução literária seja mais difundida pelo status que recebe ao longo da própria história da tradução, possuindo vasta bibliografia a respeito, estudos sobre tradução jornalística vêm ganhando mais destaque nas últimas décadas, como o livro Translation in global newss, de Esperança Bielsa e Susan Bassnett, lançado em 2009, e diversos artigos de Zipser e Polchlopek, para citar apenas alguns autores.

Apesar de haver traduções de periódicos estrangeiros desde o início da imprensa brasileira, nessas últimas décadas, com a globalização e o crescimento da Internet, as notícias circulam mais rapidamente e há um maior interesse em saber o que acontece em outros países e como o resto do mundo enxerga o Brasil e nossos problemas. É cada vez mais comum encontrarmos traduções de artigos estrangeiros em sites, jornais e revistas nacionais, tanto que a Folha de S. Paulo publica desde novembro de 2008 um caderno especial com artigos traduzidos do jornal americano The New York Times. Mesmo quando os veículos brasileiros não reproduzem as matérias na íntegra, é comum os jornalistas compilarem informações de agências internacionais e criarem um novo texto, voltado ao público-alvo de suas publicações.

Justamente por algumas características do jornalismo, como a velocidade da informação, os curtos prazos de fechamento, o espaço nos veículos impressos destinados aos artigos e à publicidade, entre outros fatores, a tradução jornalística também tem suas características, que a diferem, por exemplo, da tradução literária. 
Uma dessas características é a de que, algumas vezes, são os próprios jornalistas quem fazem as traduções, e não tradutores profissionais. É comum ainda que o nome do tradutor ou do jornalista responsável pela tradução não apareça, criando a invisibilidade do tradutor citada por Venuti (1995, p. 1-5). Esse fato contribui para que o público leigo acredite que está lendo um artigo do The New York Times ou de outra publicação estrangeira, quando, na verdade, está lendo uma tradução do texto original. Mesmo que o periódico brasileiro informe ao leitor que se trata de uma tradução, o fato de aparecerem, geralmente no alto da página, o nome do veículo estrangeiro e do jornalista que escreveu o artigo original, contribui para criar uma falsa impressão de estarmos lendo o texto-fonte.

Para Bielsa e Bassnett (2009, p. 10), no entanto, não é possível tornar o tradutor mais visível nas traduções jornalísticas:

\begin{abstract}
A tentativa de aumentar a visibilidade do tradutor é um objetivo louvável e que claramente encontra ressonância no mundo literário. No entanto, ao considerarmos a tradução jornalística, a visibilidade do tradutor é um assunto completamente diferente, e a hipótese de estrangeirização de Venuti perde validade. Na tradução jornalística, a estratégia dominante é a domesticação absoluta, pois o material é moldado para ser consumido pelo público-alvo, tendo que ser feito sob medida para atender suas necessidades e expectativas. ${ }^{2}$ (Tradução nossa).
\end{abstract}

Apesar disso, é importante desenvolver o pensamento crítico do leitor, por meio de mais trabalhos na área de tradução jornalística e debates sobre a mídia em geral, por exemplo, para que ele consiga perceber que mesmo uma tradução aparentemente literal traz escolhas linguísticas que podem alterar o significado do texto original. Algumas dessas alterações serão exemplificadas a partir dos textos selecionados, definidos na Introdução.

\footnotetext{
${ }^{2}$ Esperança Bielsa e Susan Bassnett, 2009, 10: “Making translators more visible is a laudable aim and one that clearly resonates in the literary world. However, when we consider news translation, the translator's visibility is a completely different matter, and Venuti's foreignization hypothesis ceases to hold any value. In news translation, the dominant strategy is absolute domestication, as material is shaped in order to be consumed by the target audience, so has to be tailored to suit their needs and expectations."
} 
A seleção desses artigos foi motivada pela grande repercussão que eles tiveram na mídia e na sociedade brasileira na época, a ponto de o governo brasileiro ameaçar cancelar o visto do repórter Larry Rohter, por considerar a matéria caluniosa. De acordo com o jornal Folha de S. Paulo de 14 de maio de 2004, o jornalista, após acordo de seus advogados com o governo brasileiro, afirmou em documento "jamais ter tido a intenção de ofender a honra do Excelentíssimo Senhor Presidente da República" e "manifest[ou] sua preocupação, por entender que a versão de seu texto para o português não é fidedigna, o que pode ter causado a ampliação do mal-entendido". Após essa "retratação", o cancelamento do visto foi revogado. Em seu livro Deu no New York Times (2008, p. 187), porém, Larry Rohther afirma que não houve tal retratação:

\footnotetext{
Na realidade, meus advogados tinham simplesmente preenchido o documento exigido pelas leis brasileiras para revogar uma ordem de expulsão. Nada mais, nada menos. Não havia nenhuma "carta" e certamente nenhuma "retratação".
}

Dois jornalistas da revista Época (no período da publicação dos artigos), Luiz Rila e Gustavo Krieger, sintetizaram a responsabilidade do tradutor jornalístico, em matéria que escreveram sobre a suposta retratação: "Rohter manteve o que escreveu, o governo pode dizer que recebeu um pedido de desculpas e a culpa caiu em cima do tradutor da reportagem para o português".

Se o próprio jornalista americano, mesmo obrigado pelo governo brasileiro, afirma que a versão (embora não fique claro a qual das duas versões encontradas na internet ele se refere) não é "fidedigna" ao original, quais os elementos que podemos apontar como destoantes?

\section{Fundamentação teórica}

O presente artigo está baseado em duas linhas de pesquisa principais: as modalidades de tradução propostas por Aubert (1998), a partir do modelo inicial desenvolvido por Vinay e Darbelnet ([1958] 1995), e o conceito de prosódia semântica da Linguística de Corpus, descrito no livro de Berber Sardinha 
(2004). Além disso, serão considerados os conceitos de equivalência formal e dinâmica, de Nida (1964).

Aubert (1998) propõe treze modalidades de tradução, resumidas a seguir:

Omissão: ocorre omissão sempre que um dado segmento do textofonte e a informação nele contida não podem ser recuperados no texto-meta.

Transcrição: este é o verdadeiro "grau zero" da tradução. Inclui segmentos de textos que pertençam ao acervo de ambas as línguas envolvidas (p. ex. algarismos, fórmulas algébricas e similares) ou, ao contrário, que não pertençam nem à língua fonte nem à língua meta, e sim a uma terceira língua. Ocorre, ainda, transcrição sempre que o texto-fonte contiver uma palavra ou expressão na língua-meta.

Empréstimo: um empréstimo é um segmento textual do texto-fonte reproduzido no texto-meta com ou sem marcadores específicos de empréstimo, como nomes próprios e termos e/ou expressões tendo por referentes realidades antropológicas e/ou etnológicas específicas.

Decalque: uma palavra ou expressão emprestada da língua-fonte, mas que (i) foi submetida a certas adaptações gráficas e/ou morfológicas para conformar-se às convenções da língua-fonte e (ii) não se encontra registrada nos principais dicionários recentes da língua-fonte.

Tradução literal: no modelo descrito aqui, o conceito de tradução literal é sinônimo de tradução palavra por palavra, em que, comparando-se os segmentos textuais fonte e meta, se observa: (i) o mesmo número de palavras, (ii) na mesma ordem sintática, (iii) empregando as mesmas categorias gramaticais e (iv) contendo as opções lexicais que, no contexto específico, podem ser tidas como sinônimos interlinguísticos.

Transposição: esta modalidade ocorre sempre que pelo menos um dos três primeiros critérios que definem a tradução literal deixa de ser satisfeito, ou seja, sempre que ocorrem rearranjos morfossintáticos.

Explicitação/Implicitação: informações implícitas contidas no textofonte se tornam explícitas no texto meta ou, ao contrário, informações explícitas contidas no texto-fonte tornam-se referências implícitas.

Modulação: ocorre modulação sempre que um determinado segmento textual for traduzido de modo a impor um deslocamento perceptível 
na estrutura semântica de superfície, embora retenha o mesmo efeito geral de sentido no contexto e no contexto específicos.

Adaptação: denota uma assimilação cultural, ou seja, a solução tradutória adotada para o segmento textual estabelece uma equivalência parcial de sentido, tida por suficiente para fins do ato tradutório em questão, mediante uma intersecção de traços pertinentes de sentido, mas abandona qualquer ilusão de equivalência "perfeita".

Tradução intersemiótica: figuras, ilustrações, logomarcas, selos, brasões e similares constantes do texto-fonte são reproduzidos no texto meta como material textual.

Erro: somente os casos evidentes de "gato por lebre", não incluindo as soluções tradutórias percebidas como "inadequadas", estilisticamente inconsistentes etc.

Correção: com certa frequência, o texto-fonte contém erros factuais e/ou linguísticos, inadequações e gafes. Se o tradutor opta por "melhorar" o texto meta em comparação com o texto-fonte, considera-se uma correção.

Acréscimo: trata-se de qualquer segmento textual incluído no textoalvo pelo tradutor por sua própria conta, ou seja, não motivado por qualquer conteúdo explícito ou implícito do texto original.

Baseando-se nessas modalidades, Camargo (2004, p. 11) identificou que a tradução literal (palavra por palavra) é a que predomina na tradução de textos jornalísticos, com $45 \%$ de frequência na média geral dos textos selecionados por ela. A segunda maior ocorrência é a transposição, com $26,5 \%$, categoria que ocorre quando há mudança de classe gramatical, fusão ou desdobramento, inversões de ordem ou combinações dessas alterações, sem, no entanto, haver modificação de sentido ou estilo. Em terceiro lugar, identificou-se a modulação, com 13,3\% e, em quarto lugar, tem-se o empréstimo, com $2,9 \%$.

Camargo procura explicar as tendências observadas na tradução de textos jornalísticos, em comparação com os literários e técnicos, que também foram objeto de sua análise: "o empréstimo pode representar uma economia de tempo para o tradutor ao invés de recorrer a uma solução mais complexa envolvendo adaptações; daí a sua maior incidência nos textos jornalísticos" (2004, p. 16). Na página seguinte, acrescenta: “acredita-se que as condições 
de produção de jornais e revistas e a decorrente premência do prazo levariam ao maior índice de automatismo observado". Em suas considerações finais, Camargo reforça tais características da tradução jornalística:

\begin{abstract}
Com relação ao maior uso da tradução literal nos corpora encontrar-se em textos jornalísticos, poderia atribuir-se que essa maior propensão para a literalidade seria decorrente das pressões de urgência no prazo sobre os tradutores de jornais e revistas para entregarem a matéria o mais rápido possível, o que não lhes permitiria o tempo suficiente para maiores reelaborações semânticas e estilísticas. (Camargo, 2004, p. 18)
\end{abstract}

Com base na pesquisa de Camargo poderíamos pensar que a tradução jornalística tende a ser "fiel à letra", aproximando-se ao máximo do texto original, sendo assim "neutra" e objetiva. Zipser e Polchlopek (2007, p. 5), no entanto, questionam a ideia de tradução literal ou "transcodificação isenta", por acreditar que toda tradução é um ato comunicativo e que "os textos jornalísticos trazem consigo marcas (referências) da cultura de chegada para o leitor, dependendo do contexto para o qual o fato noticioso é gerado".

As autoras citam o modelo de Christiane Nord, no qual o ato tradutório é visto como uma comunicação intercultural envolvendo o Emissor, o Tradutor (mediador) e o Receptor (leitor final). Na tradução de textos jornalísticos, para Zipser e Polchlopek (2007, p. 5), “a figura do Receptor define o que se chama de skopos (propósito) da tradução e também as estratégias, escolhas e decisões do tradutor ao longo do processo". Dessa forma, a prioridade dos textos traduzidos é que eles funcionem culturalmente para o leitor, isto é, que adquiram sentido para o receptor, o que exige da tradução jornalística uma preocupação também em termos culturais e não meramente linguísticos.

Bielsa e Bassnett (2009, p. 17) também reforçam que a tradução jornalística tem como estratégia dominante a domesticação, produzindo textos que são moldados para o público-alvo, de acordo com suas necessidades e expectativas. As autoras mencionam ainda (2009, p. 64) uma série de modificações que são frequentemente feitas nos textos traduzidos, como mudança 
de título e lead (parágrafo introdutório da matéria), eliminação de informação desnecessária, acréscimo de informação para contextualizar o leitor, mudança na ordem dos parágrafos e resumo da informação. Tais mudanças, para as autoras, costumam se justificar pelos critérios de relevância da notícia e conhecimento prévio do leitor sobre o assunto. $O$ resultado é que os textos tendem a se parecer mais com um texto original, um novo texto, criado especificamente para o público-alvo.

Conforme citado por Barbosa (1990, p. 25), Nida (1964) propõe dois tipos fundamentais de equivalência: a equivalência formal e a equivalência dinâmica. A primeira é centrada no conteúdo e na forma da mensagem (o texto original), e o tradutor está preocupado em manter a correspondência estilística, a correspondência de frase para frase e de conceito para conceito entre o texto-fonte e o texto-traduzido. Já a equivalência dinâmica tem como meta atingir uma naturalidade na expressão da mensagem do texto-fonte no textotraduzido, de modo que o leitor encontre, no texto-traduzido, modos de comportamento e elementos extralinguísticos relevantes em sua própria cultura.

Como exposto acima, as teorias de Zipser e Polchlopek e de Bielsa e Bassnett tendem a considerar que na tradução jornalística há predomínio da equivalência dinâmica, buscando aproximar o texto traduzido à cultura de chegada.

Além dessas modificações que podem ser feitas propositalmente no texto, mesmo uma tradução mais "literal" pode alterar o sentido do texto original ao levarmos em consideração o conceito de prosódia semântica.

Berber Sardinha (2004, p. 236) explica que a criação do termo “prosódia semântica" é atribuída a Sinclair e Partington e que o termo se refere a uma associação recorrente entre itens lexicais a um campo semântico, indicando certa conotação (negativa, positiva ou neutra). O teórico ressalta ainda que a prosódia semântica, embora tenha significado importante, não costuma ser indicada em dicionários ou manuais de tradução e, assim, "um tradutor pode utilizar a prosódia semântica inadequada sem saber, ao empregar termos que são tidos como equivalentes".

Como alguns exemplos, Berber Sardinha mostra, por meio de estudos de corpora, que tanto os verbos cause em inglês como "causar" em português 
têm prosódia semântica negativa, por estarem frequentemente associados a palavras como "problemas", "danos", "morte”, "prejuízo”, entre outras de conotação negativa. Por outro lado, o verbo "acontecer" em português tem uma prosódia mais positiva ou neutra, pois, embora também forme colocações com as palavras "crime" e "acidente", a maioria das colocações é vaga ou positiva, como "nada", "coisa", “evento", "jogo", "mundial”. Já o verbo happen em inglês mantém a prosódia semântica negativa, associando-se frequentemente a "acidentes", "tragédias", “crises".

Outros aspectos que norteiam o trabalho são os conceitos de objetividade e ética jornalística. Apesar de não estarem diretamente associados aos estudos de tradução, tais conceitos são fundamentais na discussão sobre o jornalismo. Bucci (2000, p. 18-21) afirma que o maior dilema ético do jornalista não é escolher entre o certo e errado, pois nesse caso seria fácil fazer a escolha pelo certo. O desafio está em tomar uma decisão entre o certo e o certo, ou seja, escolher entre duas alternativas igualmente lícitas. Como exemplo, podemos citar a decisão entre preservar a intimidade de alguém ou divulgar uma notícia sobre a vida privada de uma pessoa pública. $O$ texto escolhido para a análise levanta essa questão: o suposto problema com bebidas do expresidente Lula é um problema pessoal dele ou um assunto do Estado e, consequentemente, de interesse público? E se o texto original não for ético, sendo parcial e subjetivo, cabe ao tradutor manter-se fiel a ele ou buscar mais objetividade e imparcialidade?

\section{Metodologia}

Inicialmente fizemos a seleção dos textos pela internet, pelos motivos apresentados na justificativa, e a pesquisa de bibliografia. O segundo passo foi a leitura e cotejamento manual, para identificarmos as principais características das traduções.

Após essa fase, passamos a utilizar corpora eletrônicos, como o Corpus do Português e o Corpus of Contemporary American English (COCA) para análise da frequência de certas combinações encontradas na tradução e a prosódia semântica de alguns termos. A própria internet, por meio do buscador Google, também foi utilizada como fonte de pesquisa, embora o site não possa ser caracterizado como um corpus no sentido mais estrito da palavra. 
Foram utilizados também dicionários online, conforme citados nas referências bibliográficas.

\section{Análise}

Para facilitar a leitura, utilizamos as seguintes siglas: NYT, para referir-se ao texto-fonte, publicado no jornal The New York Times; UOL, para fazer referência ao texto traduzido publicado no portal Universo On-Line; e Folha, para o texto traduzido publicado no jornal Folha de S. Paulo.

Conforme identificado por Camargo (2004), os textos traduzidos que analisamos apresentam um predomínio de tradução literal e transposição. $\mathrm{O}$ pouco tempo disponível para as traduções jornalísticas pode explicar a tendência à tradução mais literal, num processo de automatismo. Já a transposição torna-se necessária devido às características próprias de cada língua, como a inversão da ordem dos substantivos e adjetivos, o acréscimo ou omissão de preposições, artigos e pronomes, ou a transformação de tempos verbais inexistentes em língua portuguesa, como o present perfect tense, que aparece traduzido tanto como presente do indicativo quanto como pretérito perfeito do indicativo. Os exemplos a seguir mostram tanto tradução literal como transposição, na mesma frase:

(NYT) - But some of his countrymen have begun wondering if their president's predilection for strong drinks is affecting his performance in office.

(UOL) - Mas alguns de seus conterrâneos começaram a se perguntar se a predileção do presidente por bebidas fortes está afetando sua atuação no governo.

(Folha) - Mas alguns de seus conterrâneos começam a se perguntar se sua preferência por bebidas fortes não está afetando sua performance no cargo.

Além de os textos traduzidos, no geral, terem o predomínio da tradução literal, não houve corte de parágrafos ou resumo de informações, ao contrário do que costuma acontecer, segundo Bielsa e Bassnett (2009, p. 64). Também não houve alteração significativa na ordem dos textos, os tradutores apenas quebraram alguns parágrafos em dois, possivelmente por questões estilísticas, já que normalmente não temos parágrafos muito grandes em textos jornalísticos publicados no Brasil. 
Uma possível explicação é o fato de que os textos traduzidos no Brasil costumam ser mais alterados quando se trata de notícias enviadas por agências internacionais (mantendo-se fiel ao fato-gerador e não ao texto, conforme Zipser e Polchlopek), porém tendem a ser mais literais quando são análises, comentários ou opiniões de um jornalista estrangeiro. Outra possível explicação é a própria natureza do tema: por ser um artigo polêmico, os tradutores ou editores podem ter optado por se manter o mais fiel possível para que uma possível "culpa" não recaísse sobre eles.

Apesar disso, é possível encontrar algumas alterações nos textos traduzidos, como omissões e explicitações, exemplificadas nos trechos abaixo:

(NYT) - Mr. da Silva, a 58-year-old former lathe operator

(UOL) - Lula, um ex-metalúrgico de 58 anos

(Folha) - Da Silva, um metalúrgico de 58 anos

Enquanto o UOL manteve-se mais próximo ao original, ao escrever "ex-metalúrgico", a Folha omitiu o "ex", talvez por descuido ou por opção política, qualificando o então presidente como um metalúrgico na época em que a matéria foi traduzida.

Outro trecho:

(NYT) - the columnist Claudio Humberto, a sort of Matt Drudge of Brazilian politics, sponsored a contest...

(UOL) - o colunista Claudio Humberto patrocinou um concurso...

(Folha) - o colunista Claudio Humberto, uma espécie de Matt Drudge da política brasileira, fez um concurso...

Desta vez, o UOL é que preferiu omitir a comparação do colunista brasileiro com o americano, provavelmente porque Matt Drudge não é conhecido no Brasil e fazer referência a ele não faria qualquer sentido para o público-alvo do portal. Já a Folha optou pela transposição, sem explicar quem era Matt Drudge para seus leitores. Nesse caso, se fosse para manter a "estrangeirização" do texto, uma breve nota explicativa poderia ser útil aos leitores, na forma de aposto, entre vírgulas ou entre travessões.

Em outro trecho:

(NYT) - "Pirassununga 51", which is the name of the most popular brand of cachaça.

(UOL) - "Pirassununga 51", o nome da marca mais popular de cachaça. 
(Folha) - "Pirassununga 51", nome de uma marca popular de cachaça no Brasil.

O UOL manteve-se mais próximo à tradução literal enquanto a Folha explicitou a informação "do Brasil" e omitiu o superlativo, trocando "a mais popular" por "uma marca popular". É possível que isso tenha ocorrido para não fazer propaganda gratuita da empresa de bebida.

Há também uma escolha inadequada na tradução do texto da Folha em:

(NYT) - The president has often stayed out of the public eye and left his advisers do most of the heavy lifting.

(UOL) - O presidente tem se mantido distante das atenções e deixado seus assessores fazerem grande parte do trabalho pesado.

(Folha) - O presidente tem ficado longe do alcance público nesses casos e tem deixado seus assessores encarregarem-se da maior parte do levantamento de peso.

A expressão "levantamento de peso", usada pela Folha, para "heavy lifting" não faz sentido nesse contexto; assim, a opção do UOL, "trabalho pesado", foi mais adequada.

Já neste outro trecho, ao contrário, a Folha fez uma opção mais adequada que o UOL:

(NYT) - "...you've got to get hold of this thing and control it,..."

(UOL) - “...você precisa pegar essa coisa e controlá-la,..."

(Folha) - "...e você precisa controlar isso,..."

"Pegar essa coisa" é uma transposição da expressão "get hold of this thing" que não se encaixou bem no texto traduzido, dentro de uma linguagem jornalística. A opção da Folha, em omitir a expressão e resumir o sentido, nos pareceu mais indicada.

Além dessas alterações, houve a criação de uma linha-fina (frase logo abaixo do título) na tradução do UOL, que é uma das modificações comuns apontadas por Bielsa e Bassnett.

(NYT) - Brazilian Leader's Tippling Becomes National Concern

(UOL) - Hábitos etílicos de Lula se tornam preocupação nacional - Já há quem se pergunte se a bebida estaria atrapalhando as atividades do presidente

(Folha) - Hábito de bebericar do presidente vira preocupação nacional 
Como citado anteriormente, para Zipser e Polchlopek, os textos traduzidos devem funcionar culturalmente. Seguindo essa linha, o UOL optou por utilizar apenas "Lula" para se referir ao ex-presidente, comum na cultura brasileira, ao contrário da Folha, que se manteve mais fiel à tradução literal de "Mr. da Silva", usando "Da Silva", porém sem o título de tratamento. Por não ser comum utilizarmos os sobrenomes no Brasil, a escolha do tradutor da Folha pode causar estranheza no leitor.

Exemplos:

(NYT) - Spokesmen for Mr. da Silva declined...

(UOL) - Os porta-vozes de Lula se recusaram...

(Folha) - Os porta-vozes de Da Silva recusaram-se...

\section{Prosódia semântica e registro}

Outras alterações, mais sutis, dizem respeito à prosódia semântica de alguns termos ou ao registro formal/informal. À primeira vista, algumas escolhas lexicais são ou parecem ser uma tradução literal e, portanto, as mais indicadas, porém nem sempre esses termos apresentam a mesma prosódia semântica, como demonstrando por Berber Sardinha sobre "acontecer" e "to happen", descrito na Fundamentação Teórica. Palavras aparentemente sinônimas na língua de chegada também podem apresentar prosódia diferente e, consequentemente, transmitir sentidos diferentes ao leitor.

No próprio título, podemos notar algumas diferenças:

(NYT) - Brazilian Leader's Tippling Becomes National Concern

(UOL) - Hábitos etílicos de Lula se tornam preocupação nacional

(Folha) - Hábito de bebericar do presidente vira preocupação nacional

Segundo o Webster's Online Dictionary, to tipple pode ser tanto "beber álcool frequentemente ou em excesso" como "beber álcool moderadamente, mas regularmente", sem indicação de registro formal ou informal. Já pelo Cambridge Advanced Learner's Dictionary online, tipple aparece apenas como substantivo, de registro informal, para referir-se a bebidas alcoólicas. No American Corpus, a maioria das 27 ocorrências é de ficção ou de revistas, reforçando a ideia de um termo mais informal. Assim, a opção "bebericar" da Folha parece mais próxima da informalidade do original do que os "hábitos etílicos" escolhido pelo UOL. No Corpus do Português, "bebericar" 
tem apenas uma ocorrência, em ficção; porém, pelo dicionário online Aulete, a definição é: “beber aos poucos; beber pouco, mas por muitas vezes”, sendo, portanto, próxima do encontrado para uma das definições do termo em inglês. Já "hábitos etílicos" não aparece no Corpus do Português, e a definição de "etílico" pelo Aulete é: "diz-se de álcool ou éter que contém o radical etila / Diz-se de estado causado pelo consumo de álcool”, nos parecendo, portanto, uma palavra mais técnica e formal.

Em outro trecho:

(NYT) - a shot of whiskey or, even better, a slug of cachaça

(UOL) - uma dose de uísque ou, melhor, um trago de cachaça

(Folha) - uma dose de uísque ou, melhor ainda, um copinho de cachaça

Pelo American Corpus, a slug of, com 94 ocorrências, é geralmente mais associado a bebidas alcoólicas, embora tenha aparecido também $a$ slug of water e a slug of carrot orange, entre as doze primeiras ocorrências, sendo a maioria de fontes literárias, mas três de textos de jornais ou revistas. No Corpus do Português, "um trago de" aparece sempre com bebidas alcoólicas, entre as dezoito ocorrências disponíveis. Além disso, todos os exemplos são de fontes literárias. Já "um copinho de" aparece apenas onze vezes, tanto com bebidas alcoólicas, como com outras combinações, como "um copinho de refresco", "de geleia", "de vidro", mais usado em fontes literárias. Tanto "um copinho de" como "um trago de" podem ser traduções de a slug of, já que ambos podem se referir à bebida alcoólica, no entanto, "um trago de" parece associado a bebidas mais fortes, enquanto que "um copinho de", pelo diminutivo, parece algo "menor", mais leve". Assim, a opção tanto da Folha quanto do UOL parece estar de acordo com seus títulos, a Folha tendendo a um tom mais "leve" e informal, e o UOL a um tom mais "pesado" e técnico.

Outros trechos que podem causar impressões diferentes são:

(NYT) - In recent months, Mr. da Silva's left-leaning government...

(UOL) - Nos últimos meses, o governo de esquerda de Lula...

(Folha) - Nos últimos meses, o governo esquerdista de Da Silva...

(NYT) - Leonel Brizola, the leader of the leftist Democratic Labor Party...

(UOL) - Leonel Brizola, o líder do Partido Democrático Trabalhista de esquerda...

(Folha) - Leonel Brizola, líder do esquerdista PDT... 
O texto original utiliza dois termos, left-leaning e leftist, porém cada veículo traduziu as duas ocorrências da mesma forma, o UOL optou por usar sempre "de esquerda", e a Folha preferiu manter "esquerdista".

No COCA, left-leaning tem 261 ocorrências e aparenta ter uma prosódia semântica neutra, como vemos em alguns exemplos entre as dez primeiras ocorrências:

"They also said that Mr. Obama was reinforcing the idea that his is a leftleaning administration..."

"...but he has since come to believe that even left-leaning Maryland could be receptive to a more conservative candidate"

"... who described himself as a left-leaning independent"

Já o termo leftist tem 1564 ocorrências e aparenta ter uma prosódia mais negativa, como nos trechos selecionados entre as dez primeiras ocorrências:

"She was accused of helping leftist rebels in 1995, but denies any wrongdoing."

"Berenson was arrested in 1995 accused of aiding leftist rebels."

"CAIR is the leftist and radical apologist organization for Muslims that the Obama Administration has been working with"

A associação comum de leftist com rebels ou radical, por exemplo, nos indica a prosódia semântica negativa do termo.

Pelo Corpus do Português, "de esquerda" tem 383 ocorrências e, entre as dez primeiras, também parece ter uma prosódia semântica mais neutra, aproximando-se de left-leaning em vez de leftitst:

“Quais são as chances de um líder africano de esquerda, movimentar-se, hoje, neste mundo 'globalizado'?"

"Nós entendemos que uma candidatura de esquerda, sozinha, não vai a lugar nenhum."

"No PSDB, ele dificilmente terá o apoio da estrutura de esquerda, porque essa estrutura está toda comprometida com o Governo de Pernambuco"

Já ao pesquisamos a palavra "esquerdista", encontramos apenas 24 ocorrências, como os exemplos abaixo:

“...ao ensejar a eleição de FHC, abriu-nos uma alternativa modernizante ao dirigismo esquerdista de Lula" 
“...embora soubessem que ele não tinha antecedentes de esquerdista. Não havia nada que o incriminasse. Mas havia um informante no grupo"

“...candidato de uma coligação esquerdista encabeçada por ex-guerrilheiros da Frente Farabundo Martí de Libertação Nacional FMLN."

Novamente, notamos uma prosódia semântica mais negativa, ao associar o termo "esquerdista" com críticas ao governo ou com palavras como "incriminasse" e "guerrilheiros".

Desse modo, retornando ao texto original:

In recent months, Mr. da Silva's left-leaning government...

Leonel Brizola, the leader of the leftist Democratic Labor Party...

No primeiro caso, a opção mais adequada para descrever o governo Lula e manter-se mais fiel ao original seria "de esquerda", como fez o UOL. Já no segundo caso, ao descrever o PDT, a opção mais indicada seria "esquerdista", como fez a Folha. Nenhum dos dois veículos, no entanto, utilizou termos diferentes para traduzir as duas ocorrências do texto original.

Em outro trecho ainda:

(NYT) - described the president's father, Aristides, whom he barely knew and died in 1978, as an alcoholic who abused his children.

(UOL) - descreveu repetidas vezes o pai do presidente, Aristides, a quem ele mal conheceu e que morreu em 1978, como sendo um alcoólatra que abusava de seus filhos.

(Folha) - têm repetidamente descrito o pai do presidente, Aristides - o qual ele pouco conheceu e morreu em 1978 - como um alcoólatra que maltratava suas crianças.

Segundo o Longman Dictionary of Contemporary English: child abuse é o crime de causar danos físicos, sexuais ou emocionais a uma criança. Pelo Dicionário Aulete digital, "abusar" pode ser tanto desrespeitar ou ofender alguém como estuprar ou violentar, e "maltratar" é "infringir maus tratos, bater ou espancar". Assim, tanto "abusar" como "maltratar" poderiam ser utilizados para traduzir abuse, porém, o termo "abusar", em Português, parece mais associado à definição de estuprar do que de maltratar, tornando a frase do UOL mais pesada que a da Folha. Pelo Corpus do Português, as colocações mais frequentes de abuso são "de poder", com 48 ocorrências, seguido por “sexual”, com 34 ocorrências. 
Aqui, a questão talvez não seja de buscar o termo mais equivalente ao original, mas levar em consideração a ética ao fazer uma opção por um vocábulo menos chocante para o público-alvo e para o próprio personagem da matéria.

Outro exemplo:

(NYT) - His supporters, however, deny reports of heavy drinking.

(UOL) - Mas aqueles que o apoiam negam os relatos de consumo excessivo de bebida.

(Folha) - Seus apoiadores, no entanto, negam as acusações de excesso de bebida.

Segundo o Dicionário Aulete, "acusação" é "imputação de falha ou crime, incriminação", tendo, portanto, prosódia negativa. Ao optar pelo termo, a Folha se distanciou do original reports, mais neutro, assim como "relatos", opção mais feliz feita pelo UOL. Um report, segundo o Longman, é uma "descrição escrita ou falada de um evento ou situação", mais próxima da definição de "relato" que, segundo o Aulete, é "descrição ou informação verbal acerca de evento, fato ou situação".

Outros exemplos poderiam ser selecionados, mas pelas limitações de espaço não serão incluídos no escopo deste trabalho.

\section{Considerações finais}

Notamos que as traduções analisadas se mantiveram próximas ao original, com predomínio de tradução literal e transposição, conforme descrito por Camargo, e sem corte de blocos de texto ou alteração da ordem dos parágrafos. Houve, no entanto, modificações como acréscimo de linha-fina no caso da tradução do UOL, algumas omissões, explicitação e uma escolha lexical inadequada, considerando-se as duas traduções. Percebemos ainda que, muitas vezes, as escolhas lexicais do tradutor ou editor podem indicar uma prosódia semântica diferente da do original e, assim, contribuir para a criação de um novo texto, aproximando-se das ideias de Zipser e Polchlopek e de Bielsa e Bassnett, para quem a tradução jornalística preocupa-se mais em apresentar elementos da língua e cultura de chegada do que de manter-se fiel ao original. 
Apesar das alterações notadas, ao contrário do que o jornalista Larry Rohter (ou seus advogados) possa(m) ter afirmado, as traduções não apresentaram modificações significativas que deturpassem o texto original, que já era polêmico em sua natureza. Algumas escolhas dos tradutores poderiam ter sido melhores, mas a dinâmica do jornalismo com seus curtos prazos tende a levar a um automatismo na tradução e à falta de reflexão.

O próprio Larry Rohter (2008, p. 183) afirma em seu livro que boa parte do problema pode ter sido causada pelo título da matéria, e não pelo texto em si:

\footnotetext{
Repórteres não escrevemos os títulos de suas matérias, e quando vi as palavras "Gosto do dirigente brasileiro pela bebida torna-se preocupação nacional" no alto de minha reportagem, tive de estremecer, porque suspeitava que aquilo ia criar um problema. Na matéria em si, eu era explícito em declarar que o zunzum a respeito do hábito de beber de Lula estava basicamente confinado a políticos e jornalistas e mal era percebido pela população em geral.
}

Assim, a polêmica sobre o texto pode refletir mais as escolhas dos editores, tanto americanos quanto brasileiros, em relação ao título da matéria e ao destaque dado ao artigo, do que erros de tradução ou escolhas lexicais inadequadas dos tradutores.

\section{Referências}

AUBERT, F. H. Translation modalities - a descriptive model for quantitative studies in Translatology. Romansk Forum. 6. Oslo: Universidade de Oslo: 3-28, 1997. Disponível em https://www.duo.uio.no/bitstream/handle/10852/25187/6-97.pdf?sequence=1\&isAllowed=y Acesso em 25 setembro 2015.

Modalidades de tradução: teoria e resultados. Tradterm, v. 5. nํ1, 1998.

Disponível em www.revistas.usp.br/tradterm/article/view/49775/53879. Acesso em 25 setembro 2015.

BARBOSA, Heloísa G. Procedimentos técnicos da tradução: uma nova proposta. Campinas: Editora Pontes, 1990.

BERBER SARDINHA, A. P. Linguística de corpus. Barueri: Manole, 2004. 
BIELSA, E. \& BASSNETT, S. Translation in global news. Routledge: London/New York, 2009.

BUCCI, E. Sobre ética e imprensa. São Paulo: Companhia das Letras, 2000.

CAMARGO, D. C. Uma análise de semelhanças e diferenças na tradução de textos técnicos, jornalísticos e literários. Delta, São Paulo, v. 20, no 1, junho, 2004.

Disponível em www.scielo.br/scielo.php?script=sci_arttext\&pid=S0102$44502004000100001 \& \operatorname{lng}=$ en\&nrm=iso. Acesso em 25 setebmro 2015.

FOLHA DE S. PAULO. Hábito de bebericar do presidente vira preocupação nacional.

Disponível em www1.folha.uol.com.br/fsp/brasil/fc0905200405.htm. Acesso em 25 setembro 2015.

Jornalista do "NYT" se retrata, e governo revoga expulsão. Disponível em www1.folha.uol.com.br/folha/brasil/ult96u60869.shtml. Acesso em 25 setembro 2015.

NIDA, E. Principles of correspondence, 1964. In Venuti, L. The Translation Studies Reader. Routlegde: Londres/New York, 2000.

RILA. L; KRIEGER, G. A última crise do governo. Disponível em http://revistaepoca.globo.com/Epoca/0,6993,EPT728369-1653,00.html. Acesso em 25 setembro 2015.

ROHTER, L. Brazilian leader's tippling becomes national concern. Disponível em

www.nytimes.com/2004/05/09/international/americas/09lula.html?pagewanted=1. Acesso em 25 setembro 2015.

Deu no New York Times - O Brasil segundo a ótica de um repórter do jornal mais influente do mundo. Tradução Otacílio Nunes et al. Rio de Janeiro: Objetiva, 2008.

UOL. Hábitos etílicos de Lula se tornam preocupação nacional.

Disponível para assinantes em

http://noticias.uol.com.br/midiaglobal/nytimes/ult574u3987.jhtm. Acesso em 13 julho 2010.

VENUTI, L. The translator's invisibility. Londres e Nova Iorque: Routledge, 1995. 
VINAY, Jean-Paul \& DARBELNET, J. Comparative stylistics of French and English - A methodology for translation. Trad. para o inglês: Juan Sager. Amsterdan/Philadelphia: John Benjamins, 1995.

ZIPSER, M. E. \& POLCHLOPEK, S. A. Traduzindo notícias: as possibilidades da tradução em meio jornalístico. Inventário. Salvador: UFBA, v. 6, p. 01-18, 2007.

Disponível em: www.inventario.ufba.br/06/pdf/Final_ZIPSER_rev.pdf. Acesso em 25 setembro 2015.

\section{Dicionários e corpora online}

AULETE DIGITAL - Disponível em: http://aulete.uol.com.br. Acesso em: 25 setembro 2015.

CAMBRIDGE ADVANCED LEARNER'S DICTIONARY - Disponível em http://dictionary.cambridge.org. Acesso em 25 setembro 2015.

CORPUS OF CONTEMPORARY AMERICAN ENGLISH (COCA) - Disponível em www.americancorpus.org. Acesso em: 25 setembro 2015.

CORPUS DO PORTUGUÊS - Disponível em www.corpusdoportugues.org. Acesso em: 25 setembro 2015.

LONGMAN DICTIONARY OF CONTEMPORARY ENGLISH - Disponível em: www.ldoceonline.com. Acesso em: 25 setembro 2015.

WEBSTER'S ONLINE DICTIONARY - disponível em www.websters-online-dictionary.org. Acesso em: 25 setembro 2015.

Resumo: Este trabalho analisa duas traduções de um mesmo artigo jornalístico publicado inicialmente no jornal americano The New York Times e traduzido pelo jornal brasileiro Folha de S. Paulo e pelo portal de internet Universo On-Line (UOL). Como base para a análise, foram utilizadas as modalidades de tradução propostas por Francis Aubert e o conceito de prosódia semântica da Linguística de Corpus. O trabalho foi realizado por meio de um cotejamento manual entre os três textos e também com o auxílio de corpora eletrônicos.

Palavras-chave: tradução jornalística, modalidades de tradução, prosódia semântica, Linguística de Corpus. 


\begin{abstract}
This paper analyzes two translations of the same news article originally published in the American newspaper The New York Times and translated by the Brazilian newspaper Folha de S. Paulo and by the internet portal Universo On-Line (UOL). The analysis was based on the translation modalities proposed by Francis Aubert and on the concept of semantic prosody from Corpus Linguistics. The analysis was carried out through a manual comparison among the three texts and also with the aid of electronic corpora. Keywords: journalistic translation, translation modalities, semantic prosody, Corpus Linguistics.
\end{abstract}

